\title{
INDONESIAN SALVAGE LAW WITHIN THE FRAMEWORK OF CONTEMPORARY MARITIME LAW
}

\author{
Dhiana Puspitawati \\ Lecture at Faculty of Law Brawijaya University \\ Email: dhiana@ub.ac.id
}

\begin{abstract}
Located in a strategic position, that is between two great oceans and two land masses have made Indonesia a centre of international trade and shipping. In fact, $90 \%$ of international trades are carried out through the ocean. It is therefore crucial to assure that the activities in carrying goods across the ocean are incident free. However, if accident happens, assistance from professionals to preserve items of property is desirable. In such, salvage law emerged. This paper discusses comprehensively Indonesian salvage law within the framework of contemporary maritime law. While Indonesian maritime law is mostly based on its national law on the carriage of goods by the sea, in fact, the development of maritime law is highly affected by international practices which are largely based on international conventions and regulations.

This research finds that while Indonesian salvage law can be found in Book II Chapter VII article 545-568k Wetboek Van Koophandel or known as Kitab Undang-undang Hukum Dagang (KUHD), which focused narrowly on the value of salved property as the primary measures of success, yet Indonesian salvage law has not been developed in accordance with current international salvage law, which adopted a broader and more balanced approached in both commercial and environmental aspects.

Although it is believed that such approached is "culturally unrecognized" in Indonesia, this research argued that since Indonesian waters are part of international waters, all process by waters including salvage should confirm the relevant international practices and regulations. While Indonesia has taken out salvage law from KUHD and regulates it within Act Number $17 / 2008$ on navigation, however, such act only provides one article for salvage stating that salvage will be regulates further by Ministry Regulation. Untill this paper was written no such government regulation produced yet by Indonesia. Since Indonesian waters is the centre of international navigational routes, this paper argued that it is an urgent need for Indonesia to have appropriate salvage law in place, so it can develop dinamically from shipping practice and confirm with international regulations in salvage.
\end{abstract}

Keywords: salvage law, maritime law, commercial and environmental.

\section{INTRODUCTION}

Indonesia is located at a cross-road position (posisi silang), that is between two land-masses of the world, Australia and Asia and between two great waters of the Indian and the Pacific Oceans. It is also a place where straits used for international navigation are located. Such strategic 
location of Indonesia has made Indonesia as a centre of international trade routes. ${ }^{1}$ The correlation between international trades and transportation is obvious since without transportation international trades cannot be conducted. Although there are at least six modes of transportation, ${ }^{2}$ ocean transportation is somehow still preferable. While time utility and cost utility are two important factors in determining which modes of transportation will be used, ocean transportation offers high capacity and quality. In addition to these, although the fix cost is quite high variable cost is extremely low. Thus, $90 \%$ of international trades are carried out through the ocean.

Since Indonesian waters can be considered as a short cut for international trades from the south going to north and vice-versa, crowded ocean traffic often occur in Indonesia. While this might brings advantages for Indonesia, especially related to economic factor, it also cause problem as crowded ocean traffic often lead to sea accident such as collision, fire, grounding and any other similar accident. In addition to this, unpredictable whether condition is also contributed to sea accident. Therefore, for

\footnotetext{
${ }^{1}$ Puspitawati, Dhiana, Hukum Laut atau Hukum Maritim?', Jawapos (Surabaya), 22 May 2006

${ }^{2}$ Truck, rail, ocean, air, pipeline (for gas and oli) and intermodal
}

parties involved in international trade using ocean transportation it is crucial to assure that the activities in carrying goods across the ocean are incident free. However, if accident happens, assistance from professionals to preserve items of property is desirable. In such, salvage law emerged.

This study analyzes comprehensively Indonesian salvage law within the framework of contemporary maritime law. While contemporary international salvage law adopts wider and more balanced approach in both commercial and environmental aspect, Indonesian salvage law still focused narrowly on the value of salvaged property as the primary measures of success. This research argued that since Indonesian waters are part of international waters, all process by waters including carriage of goods by sea should confirm the relevant international practices and regulations.

\section{METHODE OF RESEARCH}

This research used documents of legal instruments relating to Indonesian salvage regulations. In particular, Indonesian Shipping Law, Act no 17/2008, in specific, provisions regarding salvage were analized. It used juridical normative method and 
furthermore also look at the implementation of salvage convention 1989. This paper will analyses te development of international salvage law framework, then discuss Indonesian salvage law. Certain articles in mass media, as well as academic papers articles were extensively used

Indonesian ports official as well as shipping company were interviewed to capture their opinions, thoughts and feelings on specific issues. The analysis of salvage regulations and national act as well as regulations and their implementation will make a significant contribution to formulate proposal to salvage law.

\section{RESULT AND DISCUSSION}

\section{A. The Origin of Maritime Law and its Scope}

As with many other aspects of law, it is difficult to make a precise definition and to draw exact lines as to what falls within the definition one decides on and what falls outside. Maritime law emerged from the need of maritime states in having universal international regulations concerning the operation of ships and all of its legal implication arising from it. Thus, it is submitted that the existence of maritime law have been shaped by practical needs, rather than by pure academic activities. Therefore, it develops rapidly. Although from its very beginning maritime law has been international $^{3}$ and national maritime law is usually the implementation of international maritime law in national sphere, ${ }^{4}$ in fact historically international maritime law was rooted from British law. ${ }^{5}$ As one of developed states having many colony, United Kingdom often transport raw materials from its colony states to United Kingdom through the ocean by ships. During this process supporting regulations were formulated. Even untill nowdays, such regulations are still implemented during the carriage of goods by sea. ${ }^{6}$

Although there is no official definition of Maritime Law, but it can be described as "the set of legal rules, concepts and process that relates to navigation and process by water. Traditionally, the focus of the law is the ship, and the legal incident that arise from its operations, which are plentiful". $7 \quad$ Since international trade

\footnotetext{
${ }^{3}$ Bjune, Catherine, Introduction to Maritime Law, 2007, The international nature of maritime law can be noticed from, inter alia, ship's mobility which easily moving from one jurisdiction to another; a ship always have crews from various nationality; the language and terms used are international (Incoterm) and the source of international maritime law is international conventions.

${ }^{4}$ Bjune, 2007, ibid.

${ }^{5}$ Gordon, Robert, 'Marine Insurance', Paper presentes at Shipping Course, BI Norway dan UWM, Surabaya, Oktober-Desember (2007)

${ }^{6}$ Ibid.

${ }^{7}$ Bjune, 2007 n.Error! Bookmark not defined.
} 
involves the movement of goods across the countries each having different legal rules, parties in international trade needs uniform regulation setting up legal rules, concept and process that relates to navigation and process by water. This is what maritime law is all about. It focuses on ships and legal incidents arising from its operations.Maritime law includes two aspects, public and private law. The examples of private aspect of maritime law includes when there is a dispute involving a breach of contract from one party within carraige of goods agreement; the responsibility of carrier and also the rights and obligations of parties involving in the process of carriage of goods by sea. On the other hand, the public aspect of maritime law includes when it deals with ship registration, the management of ship crew, safety of ships and other things relating to the interests of states such as marine environment. Salvage is one of maritime law's scope having both aspects, private and public. Private aspect of salvage is when it deals with proportionality of salvage reward and marine insurance. Whereas public aspect of salvage is when it involves the mechanism of salvage itself.

\section{B. Indonesian Maritime Law}

Since it is argued that national maritime law is mostly the implementation of international maritime law, therefore, the practice of maritime law all over the world should be similar although not identical. However, in Indonesia, maritime law is termed as private law of the sea and included within the scope of Indonesian commercial law system. ${ }^{8}$ While Indonesian commercial law is the form of lex specialis of Indonesian private law, Purwosutjipto further argued that Indonesian commercial law can be defined as law of obligation, which arises from company related laws. ${ }^{9}$ Thus, it is argued that it is insufficient to put maritime law within the scope of Indonesian commercial law. This is because the origin of maritime law is international law and once more it should be remembered that national maritime law is the implementation of international maritime law. Whereas commercial law and private law are laws that developed originally within the scope of national law. Thus, it is not surprisingly that maritime law in Indonesia did not developed in accordance with international development in the same subject matter.

\footnotetext{
${ }^{8}$ Read further Purwosutjipto, HR, Pokok-Pokok Hukum Dagang (2000).

${ }^{9}$ Ibid.
} 
Indonesia maritime law is provided within the Wetboek Van Koophandel or known as Kitab Undang-undang Hukum Dagang (KUHD). KUHD was adopted from the Netherland Law and come into force in Indonesia since April 1938 by the declaration of S.1933-47 jis 38-1 and 2 . These rules has been out of date with respect to some of its provisions. For instance provisions regarding Collision, Article 534 and 544a KUHD stated that collision includes collision between ships and between ship and other objects. Meanwhile, Rule 1 of the Collision Regulation 1972 (which was amended respetivelly in 1981, 1987, 1989, 1993 dan 2001) reads: "[t]he rules apply to all vessels upon the high seas and all waters connected to the high seas and navigable by seagoing vessell" or in other word collision only includes collision between ships. Collision between ship and other object (so called allision) does not included within the definition of collision envisaged within the Collision Regulation 1972. This goes the same for carrier's limitation of liability. The amount and currency stated for limitation of liability has been out of date and not suitable with current economic conditions. Therefore, it is argued that putting maritime law within the scope of Indonesian commercial law has caused the development of such law did not in-line with its international practices and development. These following sections elaborate inconsistency between international salvage law rules and Indonesian salvage law.

\section{Historical Development of Salvage Law}

As mentioned previously, one of the scopes of maritime law is the law of salvage. While it is important in international trade that goods should reach its destination on time, there is an obligation for a ship navigating in an open sea that it should stop to help other ship which is in danger. ${ }^{10}$ To some extend, this is what it called salvage action. The problem arising from such action is that the party conducted salvage action might steal from the shipwreck, either in international waters or territorial sea of a certain state. Thus, to counter the temptation to steal from shipwrecks, traditional salvage rules emerged. The evolution of salvage principle took place for centuries. The early concept of salvage was that the salvor

\footnotetext{
${ }^{10}$ Puspitawati, Dhiana, Urgensi Pengaturan Salvage dalam Kecelakaan Kapal di Laut (Studi Sinkronisasi Hukum), Academic Research Report, Brawijaya University, Malang (2012).
} 
should be motivated to rescue ships in danger. The right of salvor was based on natural equity. Thus, salvage was aimed at saving crew and passanger as well as the property which include freight and the ship itself. However, in its development, salvors were only motivated to gain the incentive offered without any consideration whether their salving effort was successful or not.

Hence, modern salvage rule, which provided an incentive for salvage action and preserve items of property, was introduced. This is enhanced in "no cure no pay" principle and the calculation of salvage awards. A salvor who undertakes a salvage operation, and who does not succeed, will not be able to claim an award. "Salvage law has as a basis that a salvor should be rewarded for risking his life and property to rescue the property of another from peril. A vessel is consider in peril if it is in danger or could become in danger. Examples of a vessel in peril are when it is aground or in danger of going aground." ${ }^{11}$ Prior to international codification on salvage, salvage action includes: “(i) navigating or standing by a vessel in danger, (ii) rescuing persons having taken to the boat, (iii) removing vessel from a danger posed by

11 Bjune, (2007), above n. 3 another or a wreck which has fouled her, an ice float or an impending collision, (iv) rescuing a ship, cargo or people from pirates and (v) giving advice or information in order to save a vessel from a local danger."12 Furthermore, salvor can be defined as "one, who without any particular relation to the ship in distress, proffers useful service and gives it as a volunteer adventurer without any pre-existing covenant that connected him with the duty of employing himself for the preservation of that ship"13

\section{International Salvage $\mathrm{Law}^{14}$}

The first international codification related to salvage rules was the Convention for the Unification of Certain Rules of Law Respecting Assistance and Salvage at Sea (Brussels Convention 1910) which was concluded in Brussels on 23 September 1910 and revised on 27 May 1967. ${ }^{15}$ While this Convention provides provisions on traditional salvage rules, on 28 April 1989 a new Convention, International Convention

\footnotetext{
12 Bjune, Catherine, 'Salvage', presented presented at Shipping Course, 20 October-6 December 2007

13 Lord Stowell, Neptune 1824 cited in Bjune (2007), Ibid.

14 For complete historical development of Brussels Convention 1910 as well as Salvage Convention 1989 read further Kerr, Michael, 'The International Convention on Salvage 1989 - How It Came to Be?', 39 International and Comparative Law Quarterly (1990) 530.

15 UKTS 4 (1913).
} 
on Salvage (Salvage Convention 1989) was adopted in London. ${ }^{16}$ It contains 34 articles. This Convention besides adopted traditional salvage rules from Brussels Convention 1910 also added provisions in accordance with practical development of the subject. In fact the Salvage Convention 1989 was adopted based on Amoco Cadiz accident in 1978 which spills 10 million gallon crude oil in an open sea. ${ }^{17}$ Based on such accident it was realized that traditional salvage rules did not establish rules related to marine environment. This is shown by the preamble of the Salvage Convention 1989 as follows:

“... substantial developments, in particular the increased concern or the protection of the environment, have demonstrated the need to review the international rules presently contained in the Brussels Convention of 1910 ...."

New provision provided by the Salvage Convention 1989 also includes 'special compensation' in case there is potential environment issue, salvor should also do as best as he could to save marine

16 IMO Leg/Conf.7/27, 2 May 1989.

17 Amoco Cadiz was a Very Large Crude Carrier (VLCC) under the Liberian Flag of Convinience owned by Amaco. On 16 March 1978, this ship ran aground on Portsall Rocks, approximately 3 nautical miles from the coast of Britanny, France and ultimately split in three and sank, resulting in the largest oil spill of its kind in history to that date. See also Redgwell, Catherine, 'The greening of Salvage Law', Marine Policy, March (1990). environment from potential pollution. The value of this 'special compensation' will be equal to the real salvor's expenses related to salvage action plus discretionary uplift $^{18}$ of the salvor's expensed. ${ }^{19}$ Furthermore, the ship owner and cargo owner are still liable to pay the salvage award upon the preservation of the ships. Special compensation is paid by the ship owner not the cargo owner. This is because cargo owner is already liable to pay for a certain proportion of salvage award payable to the salvor. Another significant development can be read from Article 13 and 14 as follows:

"Criteria for fixing the reward

1. The reward shall be fixed with a view to encouraging salvage operations, taking into account the following criteria without regard to the order in which they are presented below:

(a) the salved value of the vessel and other property;

(b) the skill and efforts of the salvors in preventing or minimizing damage to the environment;

(c) the measure of success obtained by the salvor;

\footnotetext{
18 Article 14 of the Salvage Convention 1989

${ }^{19}$ Gordon, Robert, 'Marine Insurance', Paper presented at Shipping Course, BI Norway dan UWM, Surabaya, Oktober-Desember (2007). See also Myburgh, Paul, 'The 1989 Salvage Convention: Casualty or Cure?', New Zealand Law Journal (1996); Brice Q.C., Geoffrey, 'Salvage and the Underwater Cultural Heritage', Marine Policy, v20 n4 (1996).
} 
(d) the nature and degree of the danger;

(e) the skill and efforts of the salvors in salving the vessel, other property and life;

(f) the time used and expenses and losses incurred by the salvors;

(g) the risk of liability and other risks run by the salvors or their equipment;

(h) the promptness of the services rendered;

(i) the availability and use of vessels or other equipment intended for salvage operations;

(j) the state of readiness and efficiency of the salvor's equipment and the value thereof.

2. Payment of a reward fixed according to paragraph 1 shall be made by all of the vessel and other property interests in proportion to their respective salved values. However, a State Party may in its national law provide that the payment of a reward has to be made by one of these interests, subject to a right of recourse of this interest against the other interests for their respective shares. Nothing in this article shall prevent any right of defence.

3. The rewards, exclusive of any interest and recoverable legal costs that may be payable thereon, shall not exceed the salved value of the vessel and other property."20

Whereas Article 14 of Salvage Convention 1989 envisages:

20 Article13 of the Salvage Convention 1989
"Special compensation

1. If the salvor has carried out salvage operations in respect of a vessel which by itself or its cargo threatened damage to the environment and has failed to earn a reward under article 13 at least equivalent to the special compensation assessable in accordance with this article, he shall be entitled to special compensation from the owner of that vessel equivalent to his expenses as herein defined.

2. If, in the circumstances set out in paragraph 1, the salvor by his salvage operations has prevented or minimized damage to the environment, the special compensation payable by the owner to the salvor under paragraph 1 may be increased up to a maximum of $30 \%$ of the expenses incurred by the salvor. However, the tribunal, if it deems it fair and just to do so and bearing in mind the relevant criteria set out in article 13, paragraph 1 , may increase such special compensation further, but in no event shall the total increase be more than $100 \%$ of the expenses incurred by the salvor.

3. Salvor's expenses for the purpose of paragraphs 1 and 2 means the out-of-pocket expenses reasonably incurred by the salvor in the salvage operation and a fair rate for equipment and personnel actually and reasonably used in the salvage operation, taking into consideration the criteria set out 
in article 13, paragraph 1(h), (i) and (j).

4. The total special compensation under this article shall be paid only if and to the extent that such compensation is greater than any reward recoverable by the salvor under article 13.

5. If the salvor has been negligent and has thereby failed to prevent or minimize damage to the environment, he may be deprived of the whole or part of any special compensation due under this article.

6. Nothing in this article shall affect any right of recourse on the part of the owner of the vessel." 21

The "fair rate" in Article 14 (3) referred to the daily commercial rate for hire. Article 14, especially those related to the remuneration award, further referred to SCOPIC Clause (Special Compensation Protection and Indemnity Clause). SCOPIC Clause is formulated especially by the Sub Committee of the Salvage Liaison Group to overcome problems resulted from different interpretation of Article 14 Salvage Convention 1989 and to answer insurance problems related to the lack of information and involvement in a certain salvage case.

However, there is misunderstanding related to the application of SCOPIC Clause, which includes the expiry date and

\footnotetext{
${ }^{21}$ Article 14 of Salvage Convention 1989
}

termination of SCOPIC Clause. In relation to the earlier, while some business parties in shipping industry considered that Article 14 of Salvage Convention is still exists even if Sub-Clause 2 of the SCOPIC Clause was used or even if the parties has cancelled SCOPIC Clause based on Sub-Clause 9 the SCOPIC Clause is still applicable, in fact the whole SCOPIC Clause will replaced Article 14 of the Salvage Convention 1989. If the parties have agreed to use SOPIC Clause in determining salvor's award, it is not possible to apply Article 14 of the Salvage Convention 1989. Further misunderstanding was related to the provision of termination in Sub-Clause 9 (i). Salvors can only cancel the Salvage agreement or SCOPIC Clause based on Sub-Clause 9 (i). ${ }^{22}$ However, the ship owner can cancel the SCOPIC Clause based on Sub-Clause 9 (ii). ${ }^{23}$

\footnotetext{
${ }^{22}$ SCOPIC Clause 9 (i) relating to termination reads: "(i) The Contractor shall be entitled to terminate the services under the SCOPIC clause and the Main Agreement by written notice to owners of the vessel with a copy to the SCR (if any) and any Special Representative appointed if the total cost of his services to date and the services that will be needed to fulfil his obligations hereunder to the property (calculated by means of the tariff rate but before the bonus conferred by sub-clause 5 (iii) hereof) will exceed the sum of:

(a) The value of the property capable of being salved; and

(b) All sums to which he will be entitled as SCOPIC remuneration"

${ }^{23}$ SCOPIC Clause 9 (ii) reads:

"(ii) The owners of the vessel may at any time terminate the obligation to pay SCOPIC remuneration after the SCOPIC clause has been invoked under sub-clause 2 hereof provided that the Contractor shall be entitled to at
} 
Moreover, 'special compensation' can be paid without distinguishing the ship type and substantial type which endanger the environment. Such compensation will be paid based on 'a more generous basis.' The differences between Brussels Convention 1910 and Salvage Convention 1989 can be described in the table below:

Table 1: Differences between Brussels Convention 1910 dan Salvage Convention 1989

\begin{tabular}{|c|c|c|c|}
\hline No. & Substance & $\begin{array}{c}\text { Brussels } \\
\text { Convention } \\
1910 \\
\end{array}$ & $\begin{array}{c}\text { Salvage } \\
\text { Convention } \\
1989 \\
\end{array}$ \\
\hline 1. & $\begin{array}{l}\text { Protection of marine } \\
\text { environment }\end{array}$ & $\mathrm{x}$ & $\mathrm{V}$ \\
\hline 2. & $\begin{array}{l}\text { Special } \\
\text { Compensation- } \\
\text { SCOPIC }\end{array}$ & $\mathrm{x}$ & V \\
\hline 3. & Discretionary Uplift & $\mathrm{x}$ & V \\
\hline 4. & $\begin{array}{l}\text { Salvage } \\
\text { Contract(implied or } \\
\text { expressed) }\end{array}$ & $\mathrm{x}$ & V \\
\hline 5. & Elements of Salvage & $\mathrm{x}$ & $\mathrm{V}$ \\
\hline 6. & $\begin{array}{l}\text { No cure-No Pay } \\
\text { Principle }\end{array}$ & $\mathrm{v}$ & V \\
\hline
\end{tabular}

Note $: \mathrm{v}=$ provides $; \mathrm{x}=$ does not provide

Another international instrument related to salvage was the Code of Practice between International Salvage Union and International Group of P\&I Club. This code

least 5 clear days' notice of such termination. In the event of such termination the assessment of SCOPIC remuneration shall take into account all monies due under the tariff rates set out in Appendix A hereof including time for demobilisation to the extent that such time did reasonably exceed the 5 days' notice of termination." provides the application of Article 14 of Salvage Convention 1989. Meanwhile, for the salvor's limitation of liability was provided in the Convention on Limitation of Liability for Maritime Claims 1976.

Article 1 of the Salvage Convention 1989 defines salvage operation as: "Salvage operation means any act or activity undertaken to assist a vessel or any other property in danger in navigable waters or in any other waters whatsoever." It follows from the above definition that there are at least 4 factors regarding salvage, which include: (i) an effort conducted by salvors, (ii) at sea requirement, (iii) conducted based on voluntary nature and (iv) the salvage effort should be successful (successful service). Furthermore, salvor can be defined as:

"One, who without any particular relation to the ship ini distress, proffers useful service and gives it as a volunteer adventurer without any pre-existing covenant that connected him with the duty of employing himself for the preservation of that ship." 24

At sea requirement means that such accident should happen in navigational tidal water or in docks enclosed from tidal waters by gates,

\footnotetext{
${ }^{24}$ Lord Stowellin, Neptune, 1824 as cited in Bjune (2007), above n. 12
} 
since the tidal waters are adjacent to waters forming part of the complex of a basically tidal part of harbor. While the obligation of successful service referred to the principle of "no cure no pay," on the other hand, if cure good pay and thus reward will be given based on salvor's contribution during the salvage effort.

In theory there are two type of salvage which includes: (i) contract salvage dan (ii) pure salvage. Unlike contract salvage that operates prior the salvage operation in which the amount of reward is fix and provided within the contract salvage, in pure salvage the amount of award will be determined after the completion of salvage effort. While it is possible to include salvage contract prior to salvage effort with the approval of master, such contract does not contain the fix amount of the reward. The common salvage contract is Lloyds Open Form Salvage Contract or known as LOF. The LOF was formulated based on"no cure - no pay" principle and in case the agreement relating to the amount of award cannot be reached the arbitration will determine the amount. The LOF has undergone many changing or amandement and the final LOF known as LOF 2000. The characteristic of LOF 2000 is that it contains the obligation of salvor to also pay attention to marine environment issue during the services. This is inaccordance with the Salvage Convention 1989. Although the application of LOF 2000 should be in written form, it is believed that in emergency situation unwritten agreement to use LOF 2000 is aceptable. The amount of award then will be decide by arbitration board.

\section{E. Salvage Law in Indonesia}

Wetboek Van Koophandel or Kitab

Undang-undang Hukum Dagang (KUHD)

In Indonesia, salvage law can be found within Book II Chapter VII Article 545-568k of the Wetboek Van Koophandel or known as Kitab Undang-undang Hukum Dagang (KUHD). Such Act entered into force in Indonesia since 1 April 1938. The provisions provided within the Act were similar to the Netherlands $\mathrm{Act}^{25}$ which was entered into force effectivelly in Netherland on 22 Desember 1924 (S. Ned. 1924-573).

When the Brussels Convention entered into force Indonesia was still under the Netherland's colonalization and as such the Netherlands ratified the Convention not Indonesia. However, Indonesia also have to

\footnotetext{
${ }^{25}$ Since Indonesia was colonalized by the Netherland for almost 350 years, legal regulations in Indonesia should be in accordance with those in the Netherland.
} 
adopt the Convention through the concordation of the Netherland's act (S. Ned 1924-573), which was further adopted in Indonesia within S.1933-47 jo. 38-2. After independence, Article II of aturan peralihan UUD 1945 envisaged that as long as Indonesia has not made any changes all Netherland's legal instrument will still be enforcable. In fact S. 1933-47 jo. 38-2 has not been changed and still enforcable untill the present time. Unfortunately, in Netherlands itself such law has been revised with S. Ned. 1931-320 related to Van Hulp en Berging (Help and Rescue) and meanwhile Indonesia still use the same S. 1933-47 jo. 38-2. While provisions on salvage within KUHD mostly incorporated Brussels Convention 1910, not all provisions were adopted. Table below compares salvage law under Brussels Convention 1910 and KUHD:

Table 2: Comparison between salvage law under Brussels Convention 1910 and KUHD

\begin{tabular}{|c|l|c|c|}
\hline No & \multicolumn{1}{|c|}{ Substance } & $\begin{array}{c}\text { Brussels } \\
\text { Convention 1910 }\end{array}$ & KUHD \\
\hline 1. & $\begin{array}{l}\text { 'no cure-no pay' } \\
\text { principle }\end{array}$ & $\mathrm{v}$ & $\mathrm{X}$ \\
\hline 2. & $\begin{array}{l}\text { Master } \\
\text { Permission }\end{array}$ & $\mathrm{v}$ & $\mathrm{V}$ \\
\hline
\end{tabular}

\begin{tabular}{|c|c|c|c|}
\hline 3. & $\begin{array}{l}\text { Salvor's } \\
\text { compensation if } \\
\text { unsucessful }\end{array}$ & $\mathrm{x}$ & $\mathrm{V}$ \\
\hline 4. & $\begin{array}{l}\text { Compensation } \\
\text { upon man's life }\end{array}$ & $\begin{array}{c}\mathrm{x} \\
\text { (only given Fair- } \\
\text { share, if sucessful } \\
\text { and the amount of } \\
\text { compensation was } \\
\text { included within } \\
\text { salvage service fee } \\
\text { given) }\end{array}$ & $\begin{array}{c}\mathrm{v} \\
\text { (included } \\
\text { within } \\
\text { salvage } \\
\text { service } \\
\text { fee) }\end{array}$ \\
\hline 5. & $\begin{array}{l}\text { The use of Lloyd } \\
\text { Open Form } \\
\text { (LOF) }\end{array}$ & $\mathrm{V}$ & $\mathrm{V}$ \\
\hline
\end{tabular}

Note $\quad: \mathrm{v}=$ provides; $\mathrm{x}=$ does not

provide

Chapter VII of KUHD consists of three section, which include: (i) provisions on when a ship needs salvage, (ii) those related to hulploon (the amount of award) and (iii) intervention of the state authority with regard to the salvage. According to KUHD, the danger at sea which can be helped by other vessel in passage includes the following conditions: (i) people on board the sinking vessel, (ii) cargo from shipwreck, (iii) safety equipment of sunken vessels, (iv) grounded vessels an d(v) vessel navigation in danger. Furthermore, the salvage effort adopted by KUHD includes saving passanger and crew, finding and saving the floating cargo and also finding cargo on shore. In addition to this salvors have the obligation to return all cargo as 
well as safety equipment of the sunken vessel to the owner. If the salvor had saved passanger or crew the salvor have the right of reward from the ship owner. As such, while implicitely the obligation of the salvors to return all cargos and safety equipment found to the owner can be considered as "no cure no pay", it is not clear whether the award will only be given for succesfull services.

While not all provisions of Brussels Convention 1910 were adopted by KUHD, the replacement of the Convention by the Salvage Convention 1989, leads to the question of whether KUHD provisions concerning salvage can still be enforced. While Indonesia has not yet ratified Salvage Convention 1989, this convention has entered into force world-wide and has been used in practical navigational rules. Thus, for salvage action and services navigational practice always follows its provisions. Since Indonesia is also part of international trade actor, it is submitted that provisions on salvage within Salvage Convention 1989 should be adopted by Indonesia. On the application of Salvage Convention 1989, Lansakara stated that if a state has signed Lloyd Open Form for its consent on salvage service, it means such state will abide provisions provided by the Salvage Convention 1989 regardless of the consent to be bound uporn such Convention. ${ }^{26}$ This is because Lloyd Open Form itself contained provisions of the Convention to be applied contractually. Thus, it is submitted that by maintaining such practice, even a noncontracting parties to the Convention will be bind by the Convention.

\section{Indonesian Act on Navigation: Act No. 21/1992 and Act No. 17/2008}

Fortunately, Indonesia further realised that rules concerning shipping and navigation are very dynamic following rapid practical development. Thus, Indonesia has taken out some of maritime law (not all) from KUHD and enacted Act Number 21 Year 1992 (Act No. 21/1992) regarding navigation. This Act was further renewed and replaced by Act Number 17 Year 2008 (Act No. 17/2008) concerning the same subject matter. In fact, both Acts provides salvage rules although not in details. Act 21/1992 provides salvage rules within Chapter V on navigation. Chapter V Part I Article 7 of the Act stated:

\footnotetext{
26 Lansakara, F, 'Maritime Law of Salvage and Adequacy of Laws Protecting the Salvor's interests', International Journal on Marine Navigationand Safety of Marine Transportation, v6 n3 (2012).
} 
"Navigation includes all things related to act of navigation, telecomunication, hydrography, sea-lanes passage, pilotage, shipwreck removal, salvage and other under water works for the safety of navigation."

Furthermore, Chapter V Part V regarding shipwreck, salvage and other under-water works, Article 19 stated:

“(1) Salvage is conducted upon shipwreck and/or its cargoes and upon a vessel and/or its cargoes, which is in danger of sinking.

(2) All under-water works should meet technical requirement realting to the safety of navigation.

(3) Further regulations concerning paragraph (1) and (2) will be regulated further by government regulations."

Article 1 (8) UU 21/1992 further defines other under-water works as: “...all works related to installations, constructions and ships which is conducted uner-water or special under-water works." Meanwhile Atc $21 / 1992$ is silent on the definition of salvage or other works which can be categorized as salvage.
While Act 21/1992 includes ships and its cargoes in danger at sea or is sinking, Chapter X Part VIII Article 204 of Indonesian Act 17/2008 regarding salvage and under water works provides:

“(1) Salvage services are conducted upon shipwreck and/ its cargo which has been sunken.

(2) Every salvage services and under water works required permission and technical requirement for safety and security of navigation from Minister., 27

Furthermore Article 1 (54) of Indonesian Act No. 17/2008 defined shipwreck as "every sunken or grounded vessels which has been abandon." Article 1 (55) of Indonesian Act No. 17/2008 defines salvage as:

"services to help or recue ships and its cargoes in danger in navigational waters including removing the shipwreck and other underwaters objects." 28

Furthermore, underwaters works is defined by Article 1 ((51) Act No. 17/2008 as:

“...the works related to installations, constructions or a ship which is conducted underwater and/ underwater works, especially the

${ }^{27}$ Article 204 of Act 17/2008, translated by the Author

${ }^{28}$ Article 1 (55) Act 17/2008, translated by the Author 
operation of underwater equipment which is operated from the surface. ${ }^{, 29}$

It follows from the above, while it can be noted that under Indonesian Act No. $17 / 2008$ salvage services only referred to shipwreck removal of sunken vassel, according to Salvage Convention 1989 shipwreck removal is also part of salvage services and not merely removing shipwreck of sunken vessel but wreck of the salvaged vessel in danger of sinking. According to Bjune salvage services include even more broad activities, as stated below: ${ }^{30}$

"navigating or standing by a vessel in danger, rescuing persons having taken to the boats, removing a vessel from a danger posed by another or a wreck which has fouled her, an ice floa or an impending collision, rescuing a ship, cargoes or people in pirates, giving advice or information in order to save a vessel from a local danger, dispatching an aircraft to search and transmit the position of a derelict vessel, towing, piloting and putting out fire."

Form the above quotation it is clear that salvage services is only presented to a ship and its cargo in danger at sea and also the act of piracy or even might include

\footnotetext{
${ }^{29}$ Article 1 (51) of Indonesian Act No. 17/2008, translated by the Author

${ }^{30}$ Bjune, 2007 above $n 12$
}

terrorism, not to the existing shipwreck off shore or lying on the coast as stipulated by Article 204 (1) UU 17/2008. Unlike KUHD which clearly pointed to the master in permitting salvage services, however, it is not clear in Indonesian Act No. 17/2008 who should give permission for salvage services. In addition to this, while salvage services include the effort in rescuing a ship, cargo or people from pirates, Indonesian domestic law is silent on this matter. Thus, it is submitted that there are some inconsistency between Indonesian domestic law regarding Salvage and International regulation on the same subject. While KUHD actually contains details regulations on salvage compared to Indonesian Act on Navigation, unfortunately the formulation of KUHD was based on Brussels Convention 1910 which has been replaced by Salvage Convention 1989. The following table describes the comparison between Salvage Convention 1989 and Indonesia Act No. 17/2008:

\section{Table 3: Comparison between Salvage Convention 1989, Act 21/1992 and Act 17/2008 on Salvage Rules}

\begin{tabular}{|c|c|c|c|c|}
\hline No. & Substance & $\begin{array}{c}\text { Salvage } \\
\text { Convention } \\
1989\end{array}$ & $\begin{array}{c}\text { Act } \\
\mathbf{2 1 / 1 9 9 2}\end{array}$ & $\begin{array}{c}\text { Act } \\
\mathbf{1 7 / 2 0 0 8}\end{array}$ \\
\hline 1. & Definition of & $\mathrm{v}$ & $\mathrm{x}$ & $\mathrm{V}$ \\
\hline
\end{tabular}




\begin{tabular}{|c|c|c|c|c|}
\hline & Salvage & & & \\
\hline 2. & $\begin{array}{l}\text { Salvage } \\
\text { Services }\end{array}$ & $\begin{array}{l}\text { On ship and } \\
\text { its property } \\
\text { at the } \\
\text { navigational } \\
\text { waters (at } \\
\text { sea) }\end{array}$ & $\begin{array}{l}\text { On } \\
\text { shipwreck } \\
\text { and/or its } \\
\text { cargoes } \\
\text { dan ships } \\
\text { and/or its } \\
\text { cargoes }\end{array}$ & $\begin{array}{l}\text { On } \\
\text { existing } \\
\text { shipwreck } \\
\text { and its } \\
\text { cargo }\end{array}$ \\
\hline 3. & $\begin{array}{l}\text { Shipwreck } \\
\text { Removal }\end{array}$ & $\begin{array}{c}\mathrm{v} \\
\text { (following } \\
\text { to the } \\
\text { salvage } \\
\text { services on } \\
\text { the ship in } \\
\text { danger not } \\
\text { on an } \\
\text { existing } \\
\text { shipwreck) }\end{array}$ & $\begin{array}{c}\mathrm{V} \\
\text { (not as } \\
\text { part of } \\
\text { salvage } \\
\text { services) }\end{array}$ & $\begin{array}{c}\mathrm{v} \\
\text { (existing } \\
\text { shipwreck } \\
\text { not the } \\
\text { shipwreck } \\
\text { of the } \\
\text { ship in } \\
\text { danger) }\end{array}$ \\
\hline 4. & $\begin{array}{l}\text { Under-Water } \\
\text { Works }\end{array}$ & $\mathrm{x}$ & $\mathrm{V}$ & $\mathrm{V}$ \\
\hline 5. & $\begin{array}{l}\text { Property } \\
\text { (including } \\
\text { freight) }\end{array}$ & $\mathrm{v}$ & $\mathrm{V}$ & $\mathrm{V}$ \\
\hline 6. & $\begin{array}{l}\text { Salvor } \\
\text { Compensation }\end{array}$ & $\mathrm{v}$ & $\mathrm{x}$ & $\mathrm{X}$ \\
\hline 6. & $\begin{array}{l}\text { No Cure No } \\
\text { Pay Principle }\end{array}$ & $\mathrm{V}$ & $\mathrm{x}$ & $\mathrm{X}$ \\
\hline 7. & $\begin{array}{l}\text { Master } \\
\text { Permission }\end{array}$ & $\mathrm{v}$ & $\mathrm{x}$ & $\mathrm{X}$ \\
\hline
\end{tabular}

Note $: v=$ provide $; x=$ does not provide

In Indonesia salvage services can be stated as volunteer action. While salvage services according to Salvage Conventon 1989 does not include salvage services provided by the government authority, Article 5 of Salvage Convention stated that salvors carrying out salvage operations shall get a reward according to their national regulations. Unfortunatelly, such reward system is still non-existing in Indonesia. Article 5 of the Salvage Convention 1989:

"Salvage operations controlled by public authorities

1. This Convention shall not affect any provisions of national law or any international convention relating to salvage operations by or under the control of public authorities.

2. Nevertheless, salvors carrying out such salvage operations shall be entitled to avail themselves of the rights and remedies provided for in this Convention in respect of salvage operations.

3. The extent to which a public authority under a duty to perform salvage operations may avail itself of the rights and remedies provided for in this Convention shall be determined by the law of the State where such authority is situated." 31

Furthermore, Article 9 of the same Convention stipulated the right of coastal state as follows:

"Nothing in this Convention shall affect the right of the coastal State concerned to take measures in accordance with generally recognized principles of international law to protect its coastline or related interests from pollution or the treat of pollution following upon a maritime casualty or acts relating to such a casualty which may reasonably be expected to result in major harmful consequences, including the right of a coastal State 
to give directions in relation to salvage operation."

In conducting salvage services, while government authority often get help from salvor services company, however, the salvage job is obtained through either subcontract works or non LOF contract. In addition, none of such salvage services concerned on marine environment. While further development on Salvage took place in early 2013 by the enactment of Transportation Minister Regulation Number $71 / 2013^{32}$ or Peraturan Menteri Perhubungan Nomor 71/2013(PM 17/2013) on Salvage, nothing in the Regulation provides provisions about compensation for salvor, rights and obligation of salvor and also no provisions on environment protection. Article 205 further stated that further regulations on salvage will be regulated by Ministry Regulation. One significant development made on salvage by the Regulation is that it provides the scope of salvage, which includes both salvaging the sinking vessel or vessel in danger of sinking and shipwreck removal. Unfortunately, the rest provisions of the Regulation only stipulates the establishment

\footnotetext{
32 This enactment of this Regulation was mandated by Article 205 of the Act 17/2008 which stated that further regulations on salvage will be regulated by Ministry Regulation
}

of salvage company and its permit procedures. Such Regulation is silent on the rights of salvors with regard to compensation and its apportionment.

\section{CONCLUSION}

Maritime trade in general is the oldest international business, which was governed by the earliest examples of international law and has been amended over time as currently applicable. Since sea transportation is still preferable mode of transportation to carry out international trade, it is important to assure that international trade through the ocean is accident free. If accidents do happen, at least property of international trade can be preserved by professional salvage services.

While Purwosutjipto argued that salvage principles as explained previously in this paper is "culturally unrecognized"33 in Indonesia, it does not justify the ignorance of the opportunities offered by current international salvage principles. However, Article 204 of Indonesian Act No. 17/2008 and $P M 71 / 2013$ on salvage can be seen as a start for Indonesia to accommodate the interests of shipping in saving their property

\footnotetext{
${ }^{33}$ Read further Purwosutjipto, ( 2000), above n.8
} 
including freight during its operation. But much remain to be done, including provided provisions on salvors' rights upon succesfull salvage efforts. As an archipelagic state, through which its waters play a vital role in international trade, Indonesia should assure that foreign vessels traversing through its waters as well as Indonesian flaged vessels will get professional assistant should the accident happen. Similarly, Indonesian shipping industry should also aware of international salvage principles as provided within the Salvage Convention 1989.

\section{REFERENCES}

\section{Books/Articles/Newspaper}

Bjune, Catherine, Introduction to Maritime Law, 2007.

Bjune, Catherine, Salvage, presented at Shipping Course, 20 October-6 December 2007.

Brice Q.C., Geoffrey, 'Salvage and the Underwater Cultural Heritage', Marine Policy, v20 n4, 1996.

Gordon, Robert, 'Marine Insurance', Paper presentes at Shipping Course, BI Norway dan UWM, Surabaya, Oktober-Desember 2007.

Gordon, Robert, 'Marine Insurance', Paper presented at Shipping Course, BI Norway dan UWM, Surabaya, Oktober-Desember 2007.

Kerr, Michael, 'The International Convention on Salvage 1989 - How It Came to Be?', 39 International and
Comparative Law Quarterly (1990) 530.

Kusumaatmadja, Mochtar, Pengantar

Hukum Internasional, 1999

Lansakara, F, 'Maritime Law of Salvage and Adequacy of Laws Protecting the Salvor's interests', International Journal on Marine Navigationand Safety of Marine Transportation, v6 n3, 2012.

Myburgh, Paul, 'The 1989 Salvage Convention: Casualty or Cure?', New Zealand Law Journal, 1996.

Purwosutjipto, HR, Pokok-Pokok Hukum Dagang, 2000.

Puspitawati, Dhiana, "Hukum Laut atau Hukum Maritim?", Jawapos (Surabaya), 22 May 2006.

Puspitawati, Dhiana, Urgensi Pengaturan Salvage dalam Kecelakaan Kapal di Laut (Studi Sinkronisasi Hukum), Academic Research Report, Brawijaya University, Malang, 2012.

Puspitawati, Dhiana, Hukum Laut Internasional, Modul Ajar, Brawijaya University, 2012.

Rompas, Rizald Max, Hutabarat, Sahala dan Rompas, Julius Robert, Pengantar Ilmu Kelautan, Buku Ajar Perguruan Tinggi, Dewan Maritim Indonesia, 2007

White, Michael, Maritime Law, 2007

Wilder, Mark A, "Application of Salvage Law and the Law of Finds to Sunken Shipwreck Dicoveries," Defense Counsel Journal, January 2000, 92-105

\section{International Conventions and Domestic Legislation}

Convention for the Unification of Certain Rules of Law respecting Assistance and Salvage at Sea, Brussels, 23 September 1910. 
International Maritime Organization

Convention 1948

United Nations Convention on the Law of the Sea 1982

International Convention on Salvage, 1989, London, 28 April 1989

Code of Practice Between International salvage Union and International Group of P\&I Club

Lloyd's Open Form for Salvage

Kitab Undang Undang Hukum Dagang

Undang-Undang Nomor 21/1992 tentang Pelayaran

Undang-Undang Nomor 17/2008 tentang Pelayaran

Peraturan Menteri Perhubungan Nomor 17/2013 tentang Salvage dan/atau Pekerjaan Bawah Air 